\title{
PENGARUH DINAMISME LINGKUNGAN, KEMAMPUAN DINAMIS, DAN LITERASI KEUANGAN TERHADAP KINERJA UMKM DI KOTA MOJOKERTO
}

\author{
Mas Agung Maulana \\ Universitas Negeri Surabaya \\ mas.17080574045@mhs.unesa.ac.id
}

\begin{abstract}
SMEs are one of the economic contributors in East Java, and performance factors are one of the drivers of the advancement of SMEs. BPS 2016-2018 shows that the City of Mojokerto SMEs only contribute 0,29\%, categorized as the least East Java GRDP (Gross Regional Domestic Product) contributor among other cities. This study focuses on SMEs of Mojokerto City. This research aims to find out the influence of environmental dynamism, dynamic capabilities, and financial literacy. This research is determined as quantitative causalities. The sampling method used is random sampling. 100 SMEs were being used as a sample taken from 3553 SMEs from Mojokerto City as a population. Data analysis using multiple linear regression and test instruments using SPSS 25. The result of this research is that the variable financial literacy has a positive effect on SME performance. In contrast, the variables environmental dynamism and dynamic capabilities did not affect SME performance. Mojokerto City SMEs should be aware of financial literacy rather than environmental dynamism and dynamic capabilities to increase SMEs' performance.
\end{abstract}

Keyword: dynamic capabilities; environmental dynamism; financial literacy; SME performance

\section{PENDAHULUAN}

Usaha Mikro, Kecil, dan Menengah (UMKM) merupakan kegiatan usaha yang mampu memperluas lapangan kerja dan memberikan pelayanan ekonomi secara luas kepada masyarakat, berperan dalam proses pemerataan dan peningkatan pendapatan masyarakat, mendorong pertumbuhan ekonomi, dan mewujudkan stabilitas ekonomi nasional (Suci, 2017). Menurut RI (2008) tentang usaha mikro, kecil, dan menengah, usaha mikro, kecil, dan menengah (UMKM) adalah usaha yang diatur oleh perorangan atau badan usaha ekonomi produktif.

UMKM di Jawa Timur memiliki peranan yang cukup tinggi atas pertumbuhan ekonomi Jawa Timur dengan dibuktikan oleh data yang diterbitkan oleh DISKOPUKM (2019), bahwa UMKM berkontribusi sebesar 54,85\% terhadap Produk Domestik Regional Bruto (PDRB). Hal ini membuktikan bahwa kinerja UMKM berdampak pada ekonomi Jawa Timur. Menurut Zehir \& Balak (2018) kinerja UMKM mengacu pada tingkat keberhasilan yang dicapai organisasi melalui strategi, upaya, atau aktivitasnya pada akhir periode tertentu dan salah satu indikatornya adalah pertumbuhan penjualan dan kepuasan pelanggan.

UMKM di Jawa Timur tersebar dalam 29 kabupaten dan 9 kota. Menurut data yang yang dikeluarkan Badan Pusat Statistik BPS (2016), tercatat Jawa Timur memiliki jumlah total 9.782.622 unit UMKM. Daerah yang memiliki jumlah UMKM terbanyak berada di Kabupaten Jember sebanyak 647.416 unit UMKM, sementara daerah dengan jumlah UMKM tersedikit berada di Kota Mojokerto sebanyak 18.995 unit UMKM. perbedaan angka yang cukup jauh tersebut menyebabkan UMKM Kota Mojokerto kurang memiliki kontribusi terhadap kemajuan ekonomi di Jawa Timur. Hal ini juga diperkuat dengan data dari Badan Pusat Statistik BPS (2019), bahwa persentase PDRB Kota Mojokerto pada PDRB Jawa Timur berada di angka 0,29\%, angka ini terendah di Jawa Timur sehingga UMKM Kota Mojokerto kurang memiliki kontribusi terhadap pembangunan ekonomi. Dari pemaparan fakta dan data yang terjadi di lapangan, objek lokasi penelitian ini di Kota Mojokerto.

Menurut PEMKOTMJK (2018), kegiatan UMKM Kota Mojokerto terbagi di 3 kecamatan, yaitu Kecamatan Kranggan, Kecamatan Magersari, dan Kecamatan Prajurit Kulon. Kriteria UMKM yang berada di Kota Mojokerto seluruhnya adalah usaha mikro. PEMKOTMJK (2018) mengeluarkan data jumlah UMKM yang terdaftar dan masih beroperasi sejumlah 3.553 unit UMKM. Angka tersebut 
Mas Agung Maulana. Pengaruh Dinamisme Lingkungan, Kemampuan Dinamis, dan Literasi Keuangan terhadap Kinerja UMKM di Kota Mojokerto

sangat berbeda jauh dengan survei yang dilakukan BPS (2016). Terdapat setidaknya 15.443 unit UMKM yang belum terdaftar di Pemerintah Kota Mojokerto. Hal ini harus diperhatikan terutama bagi Pemerintah Kota Mojokerto. Menurut Laily \& Kurniawan (2016) kinerja UMKM memiliki dampak positif bagi pertumbuhan ekonomi daerah atau PDRB.

Berdasarkan fenomena yang terjadi dalam kinerja sebuah UMKM, ada beberapa faktor yang melatarbelakangi kinerja sebuah UMKM. salah satu faktor tersebut adalah dinamisme lingkungan. Menurut Okeyo (2014) dinamisme lingkungan diartikan sebagai perubahan lingkungan bisnis yang berubah secara cepat tak terarah dan tidak terprediksi. Menurut Okeyo (2014) semua bisnis termasuk UMKM dapat dibatasi pergerakannya oleh keadaan lingkungan seperti perubahan lingkungan. Machmud \& Sidharta (2016) menyatakan, bahwa dinamisme lingkungan seperti dorongan serta regulasi pemerintah berpengaruh positif bagi kinerja UMKM. Selain regulasi, dampak dari perubahan sifat konsumen seperti perubahan permintaan, inovasi, dan teknologi dapat memengaruhi kinerja UMKM (Wijbenga \& van Witteloostuijn, 2007). Mukherji \& Mukherji (2016) menyatakan bahwa dinamisme lingkungan memaksa UMKM agar mampu bertahan, mencari solusi, dan mampu mempersiapkan dampak perubahan lingkungan yang akan terjadi selanjutnya. Menurut Okeyo (2014), Permana \& Ellitan (2020) serta Haleem et al. (2018) berpendapat bahwa dinamisme lingkungan berpengaruh positif terhadap kinerja UMKM. Hal ini berbeda dengan penelitian Permana et al. (2017) dan Sandra \& Purwanto (2015) bahwa dinamisme lingkungan tidak berpengaruh signifikan terhadap kinerja UMKM.

Selain faktor perubahan lingkungan yang dinamis juga dipengaruhi faktor lain seperti kemampuan dinamis. Teece (2007) menyatakan kemampuan dinamis adalah kemampuan perusahaan dalam merubah strategi sumber daya disaat lingkungan berubah tak terkendali. Menurut Eikelenboom \& de Jong (2019) UMKM yang baik perlu memiliki kemampuan perubahan pengelolaan sumber daya seperti aset, keuangan, dan bahan baku yang baik agar bertahan pada perubahan lingkungan yang tidak dapat diprediksi. Menurut Adrian Permana \& Ellitan (2020) kemampuan dinamis memiliki dimensi seperti kemampuan untuk merasakan dan kemampuan untuk absorbs informasi. Teece (2007) berpendapat bahwa kemampuan merasakan atau sensing ini ditandai dengan kemampuan sebuah perusahaan dalam menemukan, menafsirkan, dan mengejar peluang-peluang usaha yang dapat memberikan dampak kecepatan dan ketepatan dalam berinovasi. Selain itu sebuah UMKM juga memerlukan kemampuan learning atau absorbsi. Menurut Linares et al. (2020) sebuah perusahaan memerlukan kemampuan dalam absorbsi atau, kemampuan ini diperlukan untuk mengadopsi informasi serta menggunkan atau mengimplementasikan untuk memodifikasi sumber daya dan kemampuan perusahaan sehingga perusahaan berjalan dengan tepat. Permana et al. (2017), Permana \& Ellitan (2020), dan Linares et al. (2020) mengatakan bahwa kemampuan dinamis berdampak positif terhadap kinerja UMKM. Hal ini berbeda dengan penelitian Takahashi et al. (2016) dan Eikelenboom \& de Jong (2019) bahwa kemampuan dinamis tidak berdampak pada kinerja UMKM.

Pengetahuan tentang keuangan sangat diperlukan bagi UMKM. Iramani et al. (2018) mengemukakan bahwa literasi keuangan ialah kemampuan untuk melihat, membedah, menata, dan mengomunikasikan kondisi keuangan pribadi. Menurut Koitaba et al. (2016) literasi keuangan meningkatkan transparansi, efisiensi, akurasi, dan akuntabilitas perusahaan untuk mencapai tujuan sebuah perusahaan. Siekei et al. (2013) mengemukakan bahwa pemahaman dan implementasi literasi keungan akan berdampak pada meningkatnya taraf kemampuan perusahaan dalam memberi arah kedepannya. Salah satu bentuk literasi keuangan adalah pengetahuan tentang keuangan dasar atau financial knowledge. Pengetahuan keuangan dasar ini mendorong seseorang mengelola keuangan yang dimiliki dan menganalisis sumber pendapatan serta menentukan prioritas penggunaan dana dan membuat anggaran (Iramani et al., 2018). Selain itu pemilik UMKM harus memiliki financial attitude. Menurut Eniola \& Entebang (2017) UMKM perlu menerapkan sikap keuangan menilai instrumen keuangan yang janggih dan baru untuk kepentingan jangka Panjang, seperti pemanfaatan bank dan instrumen keuangan lain. Dengan disiplinnya pemilik UMKM dalam literasi keuangan diharapkan manajer dapat menentukan arah dan mampu bersaing sehingga akan berdampak baik kepada kinerja UMKM. Menurut Eniola \& Entebang (2017), Hussain et al. (2018), dan Agyei (2018) 
literasi keuangan berpengaruh positif terhadap kinerja UMKM. Hasil penelitian ini berbeda dengan Iramani et al. (2018) bahwa literasi keuangan tidak memiliki dampak bagi kinerja sebuah UMKM.

Atas dasar fenomena gap seperti PDRB Jatim dengan nilai tertinggi yang setengahnya disumbang UMKM, PDRB Kota Mojokerto yang berbanding terbalik dengan capaian Jatim, dan fakta bahwa Kota Mojokero menyumbang paling sedikit UMKM beserta perbedaan hasil penelitian terdahulu, penelitian ini bertujuan untuk mengetahui pengaruh dari dinamisme lingkungan, kemampuan dinamis, dan literasi keuangan terhadap kinerja UMKM di Kota Mojokerto.

\section{KAJIAN PUSTAKA DAN PENGEMBANGAN HIPOTESIS}

\section{Theory of Organization and Environment}

Pada teori ini, organisasi diartikan sebagai unit sosial yang terkoordinasi untuk mencapai tujuan tertentu yang terkonsep dan memiliki hubungan dengan lingkungan eksternalnya (Önday, 2016). Menurut Önday (2016) teori organisasi adalah sistem pengetahuan yang mempelajari dan menjelaskan struktur, fungsi dan operasi organisasi, perilaku kelompok organisasi, perilaku individu, dan lingkungan. Penerapan teori ini diharapkan agar organisasi bisa meningkatkan peluang mereka menjadi sukses dalam praktik bisnis seperti strategi, keuangan, penjualan dan pemasaran, teknologi informasi, sumber daya manusia, dan operasi. Teori organisasi dan lingkungan atau theory of organization and environment pada penelitian ini digunakan untuk menjelaskan variabel dinamisme lingkungan dan kemampuan dinamis.

\section{Theory of Planned Behaviour}

Theory of Planned Behavior atau TPB (teori perilaku terencana) merupakan pengembangan lebih lanjut dari theory of reasoned action. TPB merupakan kerangka kerja konseptual yang dirancang untuk menjelaskan determinan-determinan tertentu dari perilaku (Ajzen, 1991). Menurut Ajzen (1991) Inti dari perilaku pribadi adalah bahwa perilaku dipengaruhi oleh kemauan seseorang (behaviour intention) untuk berperilaku.

Menurut Ajzen (1991) theory of planned behavior didasarkan pada anggapan bahwa manusia adalah insan yang rasional dan secara sistematis menggunakan informasi yang dimungkinkan bagi mereka. Orang-orang memertimbangkan makna aktivitas mereka sebelum memutuskan apakah akan melaksanakan tindakan tertentu. Teori perilaku terencana pada penelitian ini akan menjelaskan variabel literasi keuangan.

\section{Theory of Performance}

ToP atau Theory of Performance teori ini menjelaskan bahwa berkinerja adalah menghasilkan hasil yang bernilai. Dalam teori ini mengemukakan bahwa seorang individu atau kelompok dapat berkolaborasi untuk membuahkan sebuah hasil (Elger, 2006). Menurut Elger (2006) kinerja memiliki beberapa komponen. Komponen tersebut adalah tingkat pengetahuan, tingkat keterampilan, tingkat identitas, faktor pribadi, dan faktor tetap. Teori kinerja pada penelitian ini akan menjelaskan variabel kinerja UMKM.

\section{Kinerja UMKM}

Menurut RI (2008), Usaha mikro kecil menengah (UMKM) adalah usaha atau bisnis yang dilaksanakan oleh perorangan atau badan usaha ekonomi produktif. Ada 3 kategori kriteria pembagian pada UMKM. yang pertama adalah usaha mikro, yaitu kategori usaha ini memiliki aset maksimal 50 juta rupiah dan omzet maksimal 300 juta rupiah. Yang kedua usaha kecil, yaitu kategori usaha ini memiliki aset maksimal 50 juta rupiah sampai 100 juta rupiah dan omzet 300 juta rupiah sampai 2,5 milyar rupiah. Yang ketiga yaitu usaha menengah, yaitu kategori usaha ini memiliki aset maksimal 500 juta rupiah sampai 10 milyar rupiah dan omzet 2,5 milyar rupiah sampai 50 milyar rupiah.

Kinerja mengacu kepada kualitas yang dihasilkan sebuah organisasi. Kinerja mewakili bagaimana seorang manajer atau pemilik melakukan teknik sebuah pengoperasian sebuah organisasi. Elger 
Mas Agung Maulana. Pengaruh Dinamisme Lingkungan, Kemampuan Dinamis, dan Literasi Keuangan terhadap Kinerja UMKM di Kota Mojokerto

(2006) berpendapat bahwa kinerja mengacu pada hasil kegiatan atau investasi suatu usaha dalam periode tertentu, hasil tersebut didapat dari memadukan keterampilan dan kemampuan dalam usaha. (Hoque, 2018) berpendapat bahwasannya kinerja UMKM adalah indikator yang memfasilitasi penilaian pencapaian sebuah UMKM. Pengukuran indikator perlu dilakukan oleh UMKM agar perusahaan dapat menilai laju pertumbuhan UMKM supaya pemilik UMKM dapat melakukan evaluasi untuk periode kedepannya.

Kinerja UMKM memiliki beberapa indikator dalam pengukurannya. Salah satu indikator dari kinerja UMKM tersebut adalah sales growth, kualitas produk, dan pengembangan produk. Menurut Machmud \& Sidharta (2016) sales growth, kualitas produk, dan pengembangan produk digunakan dalam pengukuran persepsi manajer dikarenakan tujuan dari UMKM untuk bertahan, tumbuh, dan mencapai keuntungan.

\section{Dinamisme Lingkungan}

Penelitian sebelumnya menunjukkan beberapa faktor penghambat kinerja organisasi seperti dinamisme lingkungan. Dinamisme lingkungan menurut Eke et al. (2019) dan Wang (2016) adalah sebuah perubahan cepat yang tak dapat diprediksi yang merubah pola perkembangan lingkungan bisnis. Menurut Adrian Permana \& Ellitan (2020) dan Okeyo (2014) dinamisme lingkungan memiliki beberapa indikator tingkat perubahan lingkungan. Indikator-indikator tersebut meliputi perubahan regulasi pemerintah, permintaan konsumen, teknologi, dan inovasi.

Dimensi dari dinamisme lingkungan adalah perubahan regulasi pemerintah (Okeyo, 2014). Menurut Indris \& Primiana (2015) kebijakan pemerintah memiliki peran bagi UMKM sebagai penunjuk jalan dalam melakukan persaingan seperti contoh regulasi pemerintah yang membantu UMKM dalam mengekspor barang ke luar daerah, sehingga UMKM bisa dipandang dalam lingkungan pasar yang lebih luas. Menurut Okeyo (2014) perubahan permintaan adalah indikator dari dinamisme lingkungan. Secara garus besar berubahnya permintaan menentukan jumlah barang yang dikonsumsi dan akan memengaruhi penjualan serta kinerja UMKM. Pemilik UMKM harus mampu memutar strategi dan bentuk produk yang baik untuk menghadapi turbulensi sebuah permintaan. Selain indikator perubahan regulasi serta permintaan, menurut Permana et al. (2017) ada beberapa indikator perubahan yang perlu diperhatikan. Indikator tersebut adalah perubahan teknologi dan invoasi dari suatu produk. Menurut Okeyo (2014) teknologi serta inovasi memiliki peran dalam menyusun strategi pasar, di mana pada masa ini teknologi serta macam-macam inovasi terus mengalami perkembangan dan perubahan yang tidak dapat diprediksi.

\section{Kemampuan Dinamis}

Berkembangnya zaman akan memunculkan gagasan atau tren baru di dalam pasar. Menurut Frank et al. (2017) gagasan baru akan merubah gaya lingkungan pasar seperti perubahan dalam memilih barang konsumsi pada lingkungan konsumen. Teece (2007) berpendapat dengan adanya perubahan yang cepat ini, pemilik UMKM akan dihadapkan pada ketidakstabilan lingkungan bisnis yang mendorong agar pemilik UMKM mampu merasakan ancaman dan peluang bisnis, hal tersebut mendorong UMKM agar merekonstruksi ulang bisnisnya agar UMKM dapat bertahan dengan laju lingkungan yang tidak dapat diprediksi. Menurut Linares et al. (2020) dan Teece (2007) kemampuan dinamis memiliki dimensi yaitu sensing dan learning.

Kemampuan dinamis sebuah organisasi salah satunya adalah sensing atau merasakan. Menurut Teece (2007) sensing adalah merasakan kesempatan atau peluang dan ancaman dari luar sebuah organisasi. Kemampuan organisaasi dalam sensing bertujuan untuk bagaimana sebuah organisasi memahami peluang yang ada supaya dapat mencocokan diri terhadap lingkungan eksternal sehingga perusahaan mampu beroperasi dan beradaptasi di lingkungan yang kurang stabil di masa mendatang. Menurut Linares et al. (2020) learing adalah kemampuan perusahaan untuk mendapatkan pengetahuan baru dan mengaplikasikan pembaharuan dari pengetahuan tersebut ke dalam sebuah organisasi. Kemampuan dalam sensing ini bertujuan agar sebuah perusahaan akan siap menghadapi perangkap saat menjalankan bisnis dan beradaptasi dengan tanggap di lingkungan baru. 


\section{Literasi Keuangan}

Pengembangan sebuah bisnis tak pernah lepas dari sebuah pengetahuan tentang keuangan untuk mengorganisir sebuah organisasi salah satu pengetahuan keuangan adalah literasi keuangan (Iramani et al., 2018). Menurut Chepngetich (2016) literasi keuangan adalah keterampilan suatu individu mengenai faktor keuangan yang menjadikan seseorang memiliki kapabilitas untuk mengelola keuangan secara baik sehingga mereka dapat mencapai finansial yang sejahtera. Menurut Hussain et al. (2018) sebuah literasi keuangan sangat diperlukan bagi perusahaan untuk mengatasi penyebab kesenjangan keuangan, pemahaman tentang keuangan, dan implementasi keuangan dalam organisasi. Secara garis besar literasi keuangan akan mendorong terbentuknya individu yang memiliki kemampuan dan perilaku keuangan yang baik (Iramani et al., 2018). Dimensi literasi keuangan pada penelitian ini mengadopsi Eniola \& Entebang (2017) yang memiliki dimensi financial knowledge dan financial attitude.

Menurut Eniola \& Entebang (2017) secara garis besar financial knowledge mengacu kepada pemahaman konsep dasar keuangan seperti bagaimana mengukur kinerja dan kondisi bisnis. Selain itu Eniola \& Entebang (2017) berpendapat bahwa, pengetahuan keuangan dasar pada pemilik UMKM akan mendorong pemilik UMKM tahu bagaimana mengukur kinerja dan kondisi bisnis, sehingga hal tersebut akan mendukung pengambilan keputusan yang tepat bagi UMKM. Secara garis besar pemahaman tentang pengetahuan keuangan tersebut akan membentuk sifat keuangan bagi pemilik UMKM, sehingga akan tercipta konsep keuangan pengorganisasian. Di mana hal tersebut akan berdampak pada kinerja keuangan organisasi.

Herdjiono \& Damanik (2016) menjelaskan bahwa financial attitude adalah pendapat, atau penilaian terhadap keuangan. Pendapat ini diposisikan tentang bagaimana individu menilai dan menganggap penting uang di masa mendatang. Menurut Eniola \& Entebang (2017) dalam sebuah organisasi sikap keuangan diposisikan sebagai pengambilan resiko di mana pengambilan resiko ini dilakukan disaat adanya sebuah pengembangan atau proyek perusahaan seperti pembelian aset, hal ini tentunya tidak terlepas dari peminjaman modal untuk membeli suatu aset di mana pemilik UMKM akan menggunakan instrumen seperti bank untuk mendapatkan modal. Tentunya financial attitude ini sangat berdampak untuk keberlangsungan UMKM sebagai faktor pengambilan keputusan dengan melihat sisi keuangan agar tindakan dari UMKM menjadi terarah dan terukur.

\section{Hubungan antar Variabel}

Theory of Organization and Environment adalah sistem pengetahuan yang mempelajari dan menjelaskan struktur, fungsi dan operasi organisasi, perilaku kelompok organisasi, perilaku individu, dan lingkungan. Penerapan teori ini diharapkan agar organisasi bisa meningkatkan peluang mereka menjadi sukses dalam praktik bisnis seperti strategi, keuangan, penjualan dan pemasaran, teknologi informasi, sumber daya manusia, dan operasi. Pada teori ini perilaku lingkungan diartikan bisa berubah ubah yang cepat, hal ini disebut dengan dinamisme lingkungan. Dinamisme lingkungan sendiri menurut Eke et al. (2019) dan Wang (2016) adalah sebuah perubahan cepat yang tak dapat diprediksi yang merubah pola perkembangan lingkungan bisnis. Menurut Adrian Permana \& Ellitan (2020) dinamisme lingkungan dapat memengaruhi kinerja dari UMKM secara positif, temuan ini juga didukung dengan penelitian Haleem et al. (2018). Haleem et al. (2018) berpendapat bahwa berubahnya lingkungan dengan cepat dan tak terarah akan membentuk strategi baru pembentukan suatu pasar pada barang atau jasa sehingga hal tersebut dapat berpengaruh secara positif terhadap kinerja perusahaan. Eke et al. (2019) juga berpendapat bahwa perubahan permintaan yang tak pasti akan mendorong perusahaan dalam memaksimalkan strategi sehingga perusahaan yang berada pada lingkungan yang tak pasti akan meningkatakan strategi untuk bertahan dan memaksimalkan keuntungan.

\section{H1: Dinamisme lingkungan berpengaruh terhadap kinerja UMKM.}

Theory of Organization and Environment adalah sistem pengetahuan yang mempelajari dan menjelaskan struktur, fungsi dan operasi organisasi, perilaku kelompok organisasi, perilaku individu, 
Mas Agung Maulana. Pengaruh Dinamisme Lingkungan, Kemampuan Dinamis, dan Literasi Keuangan terhadap Kinerja UMKM di Kota Mojokerto

dan lingkungan. Penerapan teori ini diharapkan agar organisasi bisa meningkatkan peluang mereka menjadi sukses dalam praktik bisnis seperti strategi, keuangan, penjualan dan pemasaran, teknologi informasi, sumber daya manusia, dan operasi. Pada teori ini dijelaskan bahwa sebuah organisasi dan lingkungan memiliki hubungan seperti perubahan dalam lingkungan organisasi, lingkungan yang berubah mampu membentuk kemampuan adaptasi organisasi agar menyesuaikan dengan kondisi lingkungan, hal ini disebut kemampuan dinamis. Kemampuan dinamis adalah kemampuan sebuah UMKM dalam bertahan di lingkungan yang tak dapat diprediksi. Teece (2007) berpendapat bahwa dengan adanya perubahan yang cepat ini, pemgang UMKM akan dihadapkan pada ketidakstabilan lingkungan bisnis yang mendorong agar pemilik UMKM mampu merasakan ancaman dan peluang bisnis, hal tersebut mendorong UMKM agar merekonstruksi ulang bisnisnya agar UMKM dapat bertahan dengan laju lingkungan yang tidak dapat diprediksi. Permana et al. (2017) dan Permana \& Ellitan (2020) mengatakan bahwa kemampuan dinamis sebuah UMKM berpengaruh positif terhadap kinerja UMKM. Penemuan ini juga didukung oleh penelitian Linares et al. (2020) yang mengatakan bahwa kemampuan dinamis berdampak positif terhadap kinerja UMKM. Berbeda dengan penelitian Takahashi et al. (2016) dan Eikelenboom \& de Jong (2019) yang mengatakan bahwa kemampuan dinamis tidak berdampak pada kinerja UMKM.

H2: Kemampuan dinamis berpengaruh terhadap kinerja UMKM.

Theory of Planned Behavior didasarkan pada anggapan bahwa manusia adalah insan yang rasional dan secara sistematis menggunakan informasi yang dimungkinkan bagi mereka. Orang-orang memertimbangkan makna aktivitas mereka sebelum melaksanakan tindakan tertentu. Hal tersebut adalah bagian dari literasi keuangan. Literasi keuangan adalah keterampilan suatu individu mengenai faktor keuangan yang menjadikan seseorang memiliki kapabilitas untuk mengelola keuangan secara baik sehingga mereka dapat mencapai finansial yang sejahtera Eniola \& Entebang (2015). Menurut Hussain et al. (2018) sebuah literasi keuangan sangat diperlukan bagi perusahaan untuk mengatasi penyebab kesenjangan keuangan, pemahaman tentang keuangan, dan implementasi keuangan dalam organisasi. Secara garis besar literasi keuangan akan mendorong terbentuknya individu yang memiliki kemampuan dan prilaku keuangan yang baik (Iramani et al., 2018). Menurut Eniola \& Entebang (2017) literasi keuangan memiliki pengaruh signifikan terhadap kinerja perusahaan, hasil ini didukung oleh Agyei (2018) dan Hussain et al. (2018).

H3: Literasi keuangan berpengaruh terhadap kinerja UMKM.

Kerangka konseptual ditunjukkan pada Gambar 1.

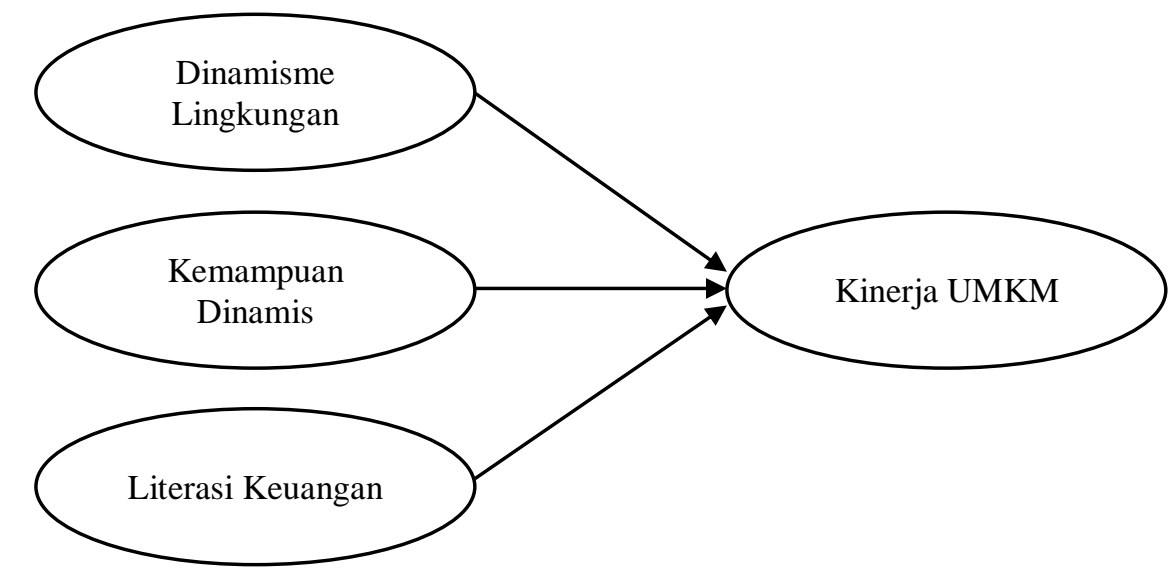

Sumber: (2021, data diolah)

Gambar 1. KERANGKA KONSEPTUAL 


\section{METODE PENELITIAN}

Penelitian ini adalah penelitian kuantitatif kausalitas. Data yang digunakan adalah data primer. Pengambilan data melalui metode wawancara, kuisoner, dan observasi. Populasi sebanyak 3553 UMKM di kota Mojokerto. Pengambilan sampel menggunakan rumus slovin dengan tingkat presesi yaitu $10 \%(\alpha=0,1)$ dalam tingkat kepercayaan yang diterima $90 \%$, Adapun rumus Slovin di persamaan (1):

$n=\frac{N}{1+N e^{2}}$

$\begin{array}{ll}\mathrm{n} & : \text { Total anggota sampel } \\ \mathrm{N} & : \text { Total populasi } \\ e^{2} & : \text { presisi }\end{array}$

$n=\frac{3553}{1+3553(0,1)^{2}}$

$n=97,26$

$n \approx 100$

Hasil dari perhitungan rumus Slovin di atas diperoleh sampel sebesar 100 responden. Teknik analisis data menggunakan regresi linier berganda dengan software Statistical Package for the Social Sciences versi 25 (SPSS). Model regresi linier di persamaan (2):

$Y=\beta_{0}+\beta_{1} X_{1}+\beta_{2} X_{2}+\beta_{3} X_{3}+e$

Pertama, dilakukan uji validitas untuk menilai efektifitas instrumen penelitian. Kemudian uji reliabilitas untuk mengukur kestabilan perangkat penelitian dalam mendapatkan hasil. Uji asumsi klasik terdiri dari uji normalitas, multikolinieritas, dan heteroskedasitas. Uji normalitas digunakan untuk mengukur apakah sebaran data berdistribusi normal. Uji multikolinieritas digunakan untuk mengetahui ada tidaknya korelasi antar variabel independen. Uji heteroskedasitas digunakan untuk mengetahui apakah dalam model regresi terdapat ketidaksamaan varian dari satu sama lain. Kemudian dilakukan uji $\mathrm{F}$ untuk memahami apakah model layak dan variabel independen bersama - sama dapat memengaruhi variabel dependen. Kemudian dilakukan uji t untuk memahami pengaruh variabel independen terhadap variabel dependen. Terakhir, dilakukan uji determinasi untuk mengetahui berapa besar pengaruh variabel independent terhadap variabel dependen. Penelitian ini menggunakan variabel indikator dari Okeyo (2014) sebagai alat ukur dinamisme lingkungan yaitu regulasi pemerintah, inovasi produk, permintaan dan teknologi. Indikator kemampuan dinamis mengadopsi penelitian Linares et al. (2020) yaitu sensing dan learning. Variabel literasi keuangan mengadopsi dimensi dari penelitian Eniola \& Entebang (2017) yaitu financial knowledge dan financial attitude.

\section{HASIL DAN PEMBAHASAN}

\section{Uji Validitas}

Hasil uji validitas skala likert pada variabel dinamisme lingkungan, kemampuan dinamis dan literasi keuangan dengan menggunakan aplikasi SPSS. Menurut Ghozali (2018:52), hasil uji validitas variabel seluruh item menghasilkan $r$ hitung $>r$ tabel. Nilai $r$ tabel untuk 100 responden sebesar 0,197. Dengan demikian jawaban responden dan item pertanyaan dinyatakan valid.

\section{Uji Reliabilitas}

Menurut Ghozali (2018:46) nilai uji reliabilitas menggunakan nilai cronbach's alpha sebesar >0,70. Tabel 1, nilai cronbach alpha untuk variabel dinamisme lingkungan sebesar 0,801, nilai cronbach 
Mas Agung Maulana. Pengaruh Dinamisme Lingkungan, Kemampuan Dinamis, dan Literasi Keuangan terhadap Kinerja UMKM di Kota Mojokerto

alpha variabel kemampuan dinamis sebesar 0,870 , dan nilai cronbach alpha variabel literasi keuangan sebesar 0,835. Dengan demikian data reliabel.

\section{HASIL UJI VALIDITAS DAN RELIABILITAS}

\begin{tabular}{cccccccc}
\hline Variable & item & $\begin{array}{c}\text { Corrected } \\
\text { item-Total } \\
\text { Correlation }\end{array}$ & $\begin{array}{c}\text { Cronbach's } \\
\text { Alpha }\end{array}$ & Variable & item & $\begin{array}{c}\text { Corrected } \\
\text { item-Total } \\
\text { Correlation }\end{array}$ & $\begin{array}{c}\text { Cronbach's } \\
\text { Alpha }\end{array}$ \\
\hline \multirow{2}{*}{ Dinamisme } & ED1 & 0,838 & & FL1 & 0,544 & \\
Lingkungan & 0,851 & 0,801 & FL2 & 0,687 & \\
& ED3 & 0,772 & & FL3 & 0,812 & \\
& ED4 & 0,705 & & Literasi & FL4 & 0,725 & \multirow{2}{*}{0,835} \\
& DC1 & 0,768 & & Keuangan & FL5 & 0,714 & \\
& DC2 & 0,746 & & & FL6 & 0,594 & \\
Kemampuan & DC3 & 0,743 & & & FL7 & 0,715 & \\
Dinamis & DC4 & 0,746 & & & & & \\
& DC5 & 0,700 & 0,870 & & & & \\
& DC6 & 0,772 & & & & & \\
& DC7 & 0,680 & & & & & \\
& DC8 & 0,648 & & & & & \\
\hline
\end{tabular}

Sumber: Output SPSS 25

\section{Uji Normalitas}

Uji normalitas dilakukan dengan uji kolmogorov-smirnov (K-S) yang menghasilkan nilai signifikansi sebesar 0,056 yang lebih besar dari 0,05 yang menunjukkan data residual berdistribusi normal, sesuai dengan Ghozali (2018:164)

\section{Uji Multikolinearitas}

Menurut Ghozali (2018:108) nilai tolerance yang digunakan pada hasil uji multikoloni adalah $\leq 0.10$, dan nilai VIF adalah $\geq 10$. Hasil menunjukkan bahwa nilai tolerance dan nilai VIF semua variabel independen dalam penelitian adalah $\leq 0.10$ dan $\geq 10$, sehingga model regresi tidak terjadi multikolinieritas.

\section{Uji Heteroskedastisitas}

Hasil uji heteroskedastisitas diamati dengan menggunakan uji gletser. Nilai uji gletser menunjukkan bahwa seluruh variabel independen berada $>0,05$, dinyatakan bahwa model regresi terbebas dari heterokedastisitas.

Tabel 2.

HASIL UJI REGRESI LINIER BERGANDA

\begin{tabular}{lcccc}
\hline Variabel & $\begin{array}{c}\text { Unstandardized } \\
\text { Coefficients }\end{array}$ & Prob & $\mathrm{t}$ & $\mathrm{Sig}$. \\
\hline (Constant) & 7,86 & 4,904 & 4,904 & 0 \\
DL & $-0,022$ & $-0,468$ & $-0,468$ & 0,641 \\
KD & 0,022 & 0,589 & 0,589 & 0,557 \\
LK & 0,108 & 2,701 & 2,701 & 0,008 \\
Uji F & & 3,232 & & 0,026 \\
Uji $R$ - & 0,063 & & & \\
Square & & & \\
Sumber: Output SPSS 25 & & &
\end{tabular}

$Y=7,860+0,108 L K+e$ 


\section{Regresi Linear Berganda}

Tabel 2 hasil regresi berganda dengan persamaan regresi (3). Persamaan regresi memberikan hasil konstan sebesar 7,860 yang artinya jika semua variabel bernilai konstan, maka kinerja UMKM yang dilakukan UMKM di Kota Mojokerto adalah 7,860. Koefisien regresi literasi keuangan memiliki nilai sebesar 0,108 satuan, artinya apabila ada peningkatan literasi keuangan sabanyak 1 satuan, maka kinerja UMKM meningkat sebesar 0,108 satuan.

\section{Uji Statistik F}

Hasil uji F diperoleh nilai $F$ hitung 3,232 dan nilai probabilitasnya 0,026. Semua variabel independen secara bersama-sama dapat memengaruhi kinerja UMKM.

\section{Uji Statistik t}

Hasil uji statistik $\mathrm{t}$ menunjukkan nilai $\mathrm{t}$ variabel literasi keuangan sebesar 2,701 dengan nilai signifikansi $0,026<0,05$. Hal tersebut menunjukkan bahwa variabel tersebut memiliki pengaruh positif signifikan terhadap kinerja UMKM. sehingga H1 diterima dan $\mathrm{H} 0$ ditolak. Variabel dinamisme lingkungan dan kemampuan dinamis memiliki nilai yang tidak signifikan terhadap kinerja UMKM, karena nilai signifikansinya lebih dari 0,05, sehingga $\mathrm{H} 0$ diterima dan $\mathrm{H} 1$ ditolak.

\section{Uji Determinasi}

Uji koefisien determinasi menunjukkan nilai adjusted $R$-square sebesar 0,063 atau 6,3\% maka variabel independen dalam penelitian ini menjelaskan 6,3\% terhadap variabel dependen, dan 93,7\% dijelaskan oleh variabel independen di luar penelitian ini. Menurut Okeyo (2014), Haleem et al. (2018), dan Haleem et al. (2018) variabel independen yang berpotensi memengaruhi variabel dependen adalah demografi dan faktor internal.

\section{Pengaruh Dinamisme Lingkungan terhadap Kinerja UMKM}

Dinamisme lingkungan terbukti tidak berpengaruh signifikan terhadap kinerja UMKM. Hal ini sejalan dengan Adriana Permana et al. (2017) dan Sandra \& Purwanto (2015) bahwa dinamisme lingkungan tidak berpengaruh signifikan terhadap kinerja UMKM. Hasil dari penelitian ini tidak sesuai dengan theory of organization and environment yang mendasari bahwa perubahan lingkungan pada organisasi akan membentuk kekuatan pada organisasi sehingga apabila organisasi mengalami perubahan yang sering akan membuat oragnisasi menjadi terlatih akan perubahan, sehingga organisasi bisa bertahan di perubahan lingkungan untuk periode kedepan (Önday, 2016).

Menurut Sandra \& Purwanto (2015) pemilik UMKM cenderung percaya bahwa tidak ada faktor eksternal yang dapat memengaruhi kinerja UMKM secara signifikan. Semua pihak yang terkait dengan UMKM khususnya pemerintah dan instansi terkait perlu memberikan perhatian khusus untuk membantu UMKM mencapai kinerja yang lebih baik seperti pengarahan, pembelajaran, dan pembenahan. Hal ini menunjukkan bahwa usaha kecil dan menengah masih mengalami kesulitan dalam memperoleh informasi atau bantuan keuangan, serta kurangnya pembinaan dan pengetahuan tentang dukungan yang diberikan, sehingga menyulitkan responden untuk mencapai kinerja usaha yang lebih baik yaitu penjualan, permodalan, laba, pasar dan pertumbuhan pendapatan, pemasaran, dan tenaga kerja tambahan (Sandra \& Purwanto, 2015).

\section{Pengaruh Kemampuan Dinamis terhadap Kinerja UMKM}

Kemampuan dinamis terbukti tidak berpengaruh signifikan terhadap kinerja UMKM. Hal ini sejalan dengan Eikelenboom \& de Jong (2019) dan Takahashi et al. (2016) bahwa kemampuan dinamis tidak berpengaruh signifikan terhadap kinerja UMKM. Hasil dari penelitian ini tidak sesuai dengan theory of organization and environment yang mendasari bahwa kemampuan organisasi dalam melakukan penyesuaian pada perubahan lingkungan organisasi, sehingga organisasi mampu bertahan dalam perubahan. Tingkat integrasi kinerja yang tinggi pada pemilik UMKM Kota Mojokerto berpotensi tidak meningkatkan kemampuan UMKM untuk membuat perubahan penting dan bergerak maju, dibuktikan dengan banyaknya pemilik UMKM yang merasa enggan untuk berubah dan menunjukkan pemikiran yang kreatif. 
Mas Agung Maulana. Pengaruh Dinamisme Lingkungan, Kemampuan Dinamis, dan Literasi Keuangan terhadap Kinerja UMKM di Kota Mojokerto

Menurut Simpson et al. (2004) tingkat kemampuan dinamis yang tinggi dapat menyebabkan kinerja yang lebih rendah, karena kinerja seringkali kurang terkait langsung dengan legalitas UMKM dan keunggulan kompetitif. Kemampuan dinamis yang tinggi dapat membatasi kemampuan pemilik UMKM dan berpotensi menyebabkan 'jebakan kompetensi' di mana organisasi menjadi lebih baik pada proses konvensional tanpa mengembangkan proses yang diperlukan untuk kinerja lingkungan.

\section{Pengaruh Literasi Keuangan terhadap Kinerja UMKM}

Literasi keuangan terbukti berpengaruh signifikan terhadap kinerja UMKM. Hal ini sejalan dengan penelitian Eniola \& Entebang (2017) bahwa literasi keuangan berpengaruh signifikan terhadap kinerja UMKM. Hasil dari penelitian ini sesuai dengan theory of planned behaviour yang mendasari bahwa literasi keuangan merupakan faktor yang dapat memengaruhi keputusan keuangan organisasi sehingga organisasi memiliki arah untuk kinerja kedepannya.

Menurut Eniola \& Entebang (2017) tingkat pengetahuan keuangan pemilik UMKM yang akan memberikan pemahaman, kemudian pemahaman tersebut akan menjadi keterampilan dan prinsip sehingga seseorang dapat menentukan situasi keuangannya sendiri dengan situasi keuangan sebagai tujuannya. Pemahaman dan implementasi literasi keuangan akan berdampak pada meningkatnya taraf kemampuan perusahaan dalam memberi arah kedepannya bagi pemilik UMKM (Iramani et al., 2018).

\section{KESIMPULAN}

Faktor terpenting yang terjadi pada UMKM Kota Mojokerto adalah literasi keuangan berpengaruh terhadap kinerja UMKM Kota Mojokerto. Hal ini disebabkan karena UMKM Kota Mojokerto menggunakan pemahaman keuangan untuk menentukan arah bisnis UMKM sehingga UMKM akan mengalami pertumbuhan kinerja yang baik. Sedangkan dinamisme lingkungan dan kemampuan dinamis tidak berpengaruh signifikan terhadap kinerja UMKM, karena banyaknya UMKM merasa tidak ada faktor eksternal yang berpengaruh terhadap kinerja UMKM dan banyak pemilik UMKM yang tidak suka menerapkan kompetensi untuk beradaptasi dengan perubahan lingkungan eksternal.

Hasil penelitian ini diharapkan dapat digunakan untuk bahan pertimbangan dan kajian bagi pemerintah Kota Mojokerto dan pihak terkait untuk memberikan sosialisasi, edukasi, pelatihan, dan coaching mengenai literasi keuangan pada UMKM dapat berimplikasi pada kinerja yang juga turut meningkatkan PDRB Kota Mojokerto agar bisa turut bersaing dengan kota lain. Keterbatasan dari penelitian ini adalah jumlah sampel yang sedikit dan kondisi lingkungan pada saat diadakan penelitian ini dalam kondisi yang kurang stabil. Rekomendasi bagi penelitian selanjutnya dapat memertimbangkan penggunaan variabel demografi dan lingkungan internal.

\section{DAFTAR PUSTAKA}

Agyei, S. K. (2018). Culture, Financial Literacy, and SME Performance in Ghana. Cogent Economics and Finance, 6(1), 1-16. https://doi.org/10.1080/23322039.2018.1463813

Ajzen, I. (1991). The Theory of Planned Behavior. Organizational Behavior and Human Decision Processes, 50(2), 179-211. https://doi.org/10.1016/0749-5978(91)90020-T

BPS. (2016). Sensus Ekonomi 2016 dan Sutas 2018. In Http://Diskopukm.Jatimprov.go.id (2-4). (http://diskopukm.jatimprov.go.id/info/data-ukm, diakses pada 25 maret 2021)

BPS. (2019). Produk Domestik Regional Bruto Kabupaten/Kota di Provinsi Jawa Timur (120). (https://jatim.bps.go.id/publication/2020/12/17/0ee19b4e545a453921bfc18b/produk-domestikregional-bruto-kabupaten-kota-di-provinsi-jawa-timur-menurut-pengeluaran-2015-2019.html, diakses pada 25 maret 2021)

Chepngetich, P. (2016). Effect of Financial Literacy and Performance SMEs. Evidence from Kenya. American Based Research Journal, 5(2016-11), 26-35. http://www.abrj.org 
DISKOPUKM. (2019). Dinas Koperasi, Usaha Kecil dan Menengah Provinsi Jawa Timur (1-62). (http://diskopukm.jatimprov.go.id/info/data-ukm, diakses pada 25 maret 2021).

Eikelenboom, M., \& de Jong, G. (2019). The Impact of Dynamic Capabilities on The Sustainability Performance of SMEs. Journal of Cleaner Production, 235, 1360-1370. https://doi.org/10.1016/j.jclepro.2019.07.013

Elger, D. (2006). Faculty guidebook: A comprehensive tool for improving faculty performance (4th ed.). Illinois: Pacific Crest.

Eniola, A. A., \& Entebang, H. (2015). Financial Literacy and SME Firm Performance. International Journal of Research Studies in Management, 5(1), 31-43. https://doi.org/10.5861/ijrsm.2015.1304

Eniola, A. A., \& Entebang, H. (2017). SME Managers and Financial Literacy. Global Business Review, 18(3), 559-576. https://doi.org/10.1177/0972150917692063

Eresia-Eke, C., Dele-Ijagbulu, O., \& Moos, M. (2019). The Nexus of Environmental Dynamism and Dimensions of Entrepreneurial Orientation in Small Businesses. Academy of Entrepreneurship Journal, 25(4), 1-12.

Frank, H., Güttel, W., \& Kessler, A. (2017). Environmental Dynamism, Hostility, and Dynamic Capabilities in Medium-sized Enterprises. International Journal of Entrepreneurship and Innovation, 18(3), 185-194. https://doi.org/10.1177/1465750317723219

Ghozali, I. (2018). Aplikasi Analisis Multivariate dengan Program IBM SPSS 25 (9th ed.). Semarang: Badan Penerbit Universitas Diponegoro.

Haleem, F., Jehangir, M., \& Haq, Z. U. (2018). Link between Environmental Dynamism and Firm Performance: The role of Strategic Planning. Journal of Managerial Sciences, August 2019.

Herdjiono, I., \& Damanik, L. A. (2016). Pengaruh Financial Attitude,Financial Knowledge, Parental Income Terhadap Financial Management Behavior. Jurnal Manajemen Teori Dan Terapan| Journal of Theory and Applied Management, 9(3), 226-241. https://doi.org/10.20473/jmtt.v9i3.3077

Hernández-Linares, R., Kellermanns, F. W., \& López-Fernández, M. C. (2020). Dynamic Capabilities and SME Performance: The moderating effect of market orientation. Journal of Small Business Management, 59(1), 162-195. https://doi.org/10.1111/jsbm.12474

Hoque, A. S. M. M. (2018). The Effect of Entrepreneurial Orientation on Bangladeshi SME Performance: Role of Organizational Culture. International Journal of Data and Network Science, 1-14. https://doi.org/10.5267/j.ijdns.2018.7.001

Hussain, J., Salia, S., \& Karim, A. (2018). Is knowledge that Powerful? Financial Literacy and Access to Finance: An Analysis of Enterprises in The UK. Journal of Small Business and Enterprise Development, 25(6), 985-1003. https://doi.org/10.1108/JSBED-01-2018-0021

Indris, S., \& Primiana, I. (2015). Internal and External Environment Analysis on The Performance of Small and Medium Industries SMES in Indonesia. International Journal of Scientific \& Technology Research, 4(4), 188-196.

Iramani, Fauzi, A. A., Wulandari, D. A., \& Lutfi. (2018). Financial Literacy and Business Performances Improvement of Micro, Small, Medium-sized Enterprises in East Java Province, Indonesia. International Journal of Education Economics and Development, 9(4), 303-323. 
Mas Agung Maulana. Pengaruh Dinamisme Lingkungan, Kemampuan Dinamis, dan Literasi Keuangan terhadap Kinerja UMKM di Kota Mojokerto

https://doi.org/10.1504/IJEED.2018.096069

Iramani, I., Suryani, T., \& Lindiawati, L. (2018). SME's Financial Literacy: An Overview Based on Demographic Aspects. Journal of Economics, Business \& Accountancy Ventura, 20(3), 283294. https://doi.org/10.14414/jebav.v20i3.1098

Koitaba, E., Waiganjo, M., \& Wanyoike, S. (2016). An Analysis of Factors Influencing Financial Control Practices in Community Based Organizations in Baringo County, Kenya. British Journal of Economics, Management \& Trade, 11(2), 1-10. https://doi.org/10.9734/bjemt/2016/20158

Laily, N., \& Kurniawan, R. Y. (2016). Analisis Pengaruh Perkembangan Usaha Kecil Menengah (Ukm) Terhadap Pertumbuhan Produk Domestik Regional Bruto (PDRB). Jurnal Pendidikan Ekonomi (JUPE), 4(3), 1-4. https://doi.org/10.26740/jupe.v4n3.p

Machmud, S., \& Sidharta, I. (2016). Entrepreneurial Motivation and Business Performance of SMEs in The SUCI Clothing Center, Bandung, Indonesia. DLSU Business and Economics Review, 25(2), 63-78.

Mukherji, A., \& Mukherji, J. (2016). Environmental Uncertainty and Positive Performance of Small Firms: The Roles of Key Mediators. Academy of Management Proceedings, 2016(1), 10437. https://doi.org/10.5465/ambpp.2016.10437abstract

Okeyo, W. O. (2014). The Influence of Business Environmental Dynamism, Complexity and Munificence on Performance of Small and Medium Enterprises in Kenya. International Journal of Business and Social Research, 4(8), 59-73. https://doi.org/10.18533/ijbsr.v4i8.587

Önday, Ö. (2016). Theories of Organizations and Environments: from Organizations and System Concept of Katz \& Kahn to Corporations and Industries of Carroll \& Hannan. Elixir International Journal, 92, 39030-39035. (https://www.researchgate.net/publication/309036911_Theories_of_Organizations_and_Enviro nments_From_Organizations_and_System_Concept_of_Katz_Kahn_to_Corporations_and_Ind ustries_of_Carroll_Hannan)

PEMKOTMJK. (2018). Pelaku UMKM di Kota Mojokerto. Laporan Dinas Koperasi Kota Mojokerto, 1(1), 1-26.

Permana, Adrian, \& Ellitan, L. (2020). The Role of Dynamic Capability in Mediating The Effects of Environmental Dynamism and Managerial Capabilities on Firm Performance: a Preliminary Study. Journal of Entrepreneurship \& Business, 1(9), 1689-1699.

Permana, Adriana, Arsono, L., \& Ellitan, L. (2017). The Effect of Environmental Dynamism, Dynamic Managerial Capabilities, and Deliberate Organizational Learning on The SME Performance With Dynamic Capabilities as Mediator Variable. International Journal of Advanced Research, 5(7), 540-551. https://doi.org/10.21474/ijar01/4750

RI, U. (2008). Undang-Undang RI No. 20 tentang UMKM.

Sandra, A., \& Purwanto, E. (2015). Pengaruh Faktor-Faktor Eksternal dan Internal Terhadap Kinerja Usaha Kecil dan Menengah di Jakarta. Business Management, 11(1), 97-124.

Siekei, J., Wagoki, J., \& Kalio, A. (2013). An Assessment of The Role of Financial Institutions in Financing Small and Medium Enterprises (SME's) in Ghana. International Journal of Innovative Research \& Development, 2(8), 111-124. 
Simpson, M., Taylor, N., \& Barker, K. (2004). Environmental Responsibility in SMEs: Does It Deliver Competitive Advantage? Business Strategy and the Environment, 13(3), 156-171. https://doi.org/10.1002/bse.398

Suci, Y. R. (2017). Perkembangan UMKM (Usaha Mikro Kecil Menengah) di Indonesia. Jurnal Ilmiah Fakultasi Ekonomi, 6(1), 51-58.

Takahashi, A. R. W., Bulgacov, S., Giacomini, M. M., \& dos Santos, C. B. (2016). Dynamic Capabilities, Political External Relationship, Educational Technology Capability and Firm Performance. International Business Management, 10(5), 652-658). https://doi.org/10.3923/ibm.2016.652.658

Teece, D. J. (2007). Explicating Dynamic Capabilities: The Nature and Microfoundations of (Sustainable) Enterprise Performance. Business, 1350(February 2004), 1-43. https://doi.org/10.1002/smj.640

Wang, Y. (2016). Environmental Dynamism, Trust and Dynamic Capabilities of Family Businesses. International Journal of Entrepreneurial Behavior \& Research 1710(1), 380-408. http://dx.doi.org/10.1108/13552551111139638\%5Cn

Wijbenga, F. H., \& van Witteloostuijn, A. (2007). Entrepreneurial Locus of Control and Competitive Strategies - The moderating Effect of Environmental Dynamism. Journal of Economic Psychology, 28(5), 566-589. https://doi.org/10.1016/j.joep.2007.04.003

Zehir, C., \& Balak, D. (2018). Market Dynamism and Firm Performance Relation: The Mediating Effects of Positive Environment Conditions and Firm Innovativeness. EMAJ: Emerging Markets Journal, 8(1), 45-51. https://doi.org/10.5195/emaj.2018.152 